\title{
An appraisal of financial indicators for local government: a structured literature review
}

\author{
Silvia Iacuzzi \\ Department of Economics and Statistics, University of Udine, Udine, Italy
}

LG financial indicators

\begin{abstract}
Purpose - Considering the increased financial responsibility of local government (LG), the impact of global crises and the growing adoption of accrual accounting and common standards such as IPSAS, this work focuses on financial indicators for LGs. It explores whether the literature on financial indicators has grown, investigates whether there is any consensus on which indicators to use for assessing LG's financial condition, develops a critical reading of the literature and offers suggestions for future research and policy agendas.

Design/methodology/approach - A structured literature review was carried out for publications in English about LG financial indicators.

Findings - Results reveal that the number of publications dealing with financial indicators has increased over the past ten years. However, rather than focusing on a set of common indicators, the literature reports a plethora of different ones used for four main purposes: transparency and accountability compliance, performance monitoring and benchmarking, assessing LG's financial health and helping deal with exogenous crises. There is no evidence of convergence towards a common set of indicators, even though liquidity and solvency are the most popular dimensions explored by scholars.

Research limitations/implications - Findings highlight the challenges in converging on financial indicators, yet no claim can be made beyond the reviewed material.

Practical implications - Results provide legislators, public managers, investors and rating agencies with insights about trends in financial indicators, their benefits and limitations.

Originality/value - The article focuses on a less popular aspect of recent financial management reforms for local administration, that is the growing fragmentation in LG indicators, accentuated by the need for common assessment tools during unprecedented widespread crises across countries and sectors.
\end{abstract}

Keywords Local administration, Financial performance, Public sector, Financial sustainability, Financial health

Paper type Research paper

\section{Introduction}

Recent public sector reforms aiming at improving transparency, intergenerational equity, management capabilities, efficiency and effectiveness have led to more decentralized systems of public finance, accompanied by a reduction in central government transfers (Pollitt and Bouckaert, 2017). This has shifted the responsibility for managing financial resources from central government to local authorities and has been accompanied by the introduction of accrual accounting and common standards such as IPSAS (International Public Sector Accounting Standards) to increase accountability, transparency and budget control (Pina et al., 2009). Due to their greater financial autonomy, local governments (LGs) increasingly

(C) Silvia Iacuzzi. Published by Emerald Publishing Limited. This article is published under the Creative Commons Attribution (CC BY 4.0) licence. Anyone may reproduce, distribute, translate and create derivative works of this article (for both commercial and non-commercial purposes), subject to full attribution to the original publication and authors. The full terms of this licence may be seen at http:// creativecommons.org/licences/by/4.0/legalcode

The author is grateful to the PA group at the Department of Economics and Statistics, University of Udine for their assistance in conducting the SLR and to the two anonymous reviewers for their insightful comments which have improved the quality of the paper. 
JPBAFM 34,6 need to resort to various forms of borrowing, which in turn may require a thorough assessment of their creditworthiness to fulfill international standards and agreements such as Basel II (Manes Rossi, 2011). Moreover, in Europe a broad debate about the harmonization of public sector accounting standards is underway with accrual accounting as its core pillar to better satisfy the need for accountability (Manes Rossi et al., 2016), even though common accounting principles are being promoted at great expense and with major challenges (Adhikari and Gårseth-Nesbakk, 2016). Lastly, it is becoming ever more necessary to assess LG's vulnerability and promote their resilience to exogenous crises such as the 2008 credit crunch or the 2020 pandemic (Ahrens and Ferry, 2020; Hruza, 2015). Therefore, the pressures to adopt common accounting standards and the growing need to assess LG's financial condition should have favored the development and dissemination of common accounting tools.

The literature contains numerous approaches to evaluating and reporting on the financial condition of public organizations, one of which is the use of financial indicators, that is indices derived from financial statements (Hruza, 2015; Rivenbark and Roenigk, 2011). Such measures, which are also referred to as fiscal or budgetary indicators, are based on a large variety of techniques, ranging from basic approaches such as accounting ratios to more sophisticated statistical models (Caruana et al., 2019; Cohen et al., 2012; Manes Rossi et al., 2017). National standard setters and regulators have themselves developed several frameworks to assess LG's financial condition (Pina et al., 2009).

Through a structured literature review (Massaro et al., 2016) this paper aims to: (1) investigate the developments of the literature on financial indicators and, in particular, whether it has grown alongside recent LG's reforms and global crises; (2) develop a critical reading of the literature on LG financial indicators and appreciate whether there is consensus among scholars on the indicators used to assess LG's financial condition and (3) offer suggestions for future research and policy agendas.

This investigation has implications for both the research and practice of public administration and management since developing valid financial measures may help improve the performance of public organizations (Kioko et al., 2011). Results are relevant from an academic perspective as they shed further light on a less popular aspect of recent financial management reforms for local administration, that is the potential benefits and limitations in developing common financial indicators and using them to assess LG's condition. Financial indicators are tools of "accounting performativity" (Bracci et al., 2015), that is they help in directing decisions and informing policy choices. Hence, findings are also relevant for practice, since they provide legislators, public managers, investors and rating agencies with insights about financial indicators, their features and use at a time when there is an increasing search for tools which can help assess and monitor LG's vulnerability (Padovani et al., 2021).

\section{Materials and methods}

A movement towards internationally standardized and recognized public sector financial reporting started at the end of the 1990s. This standardization process is led by the International Federation of Accountants (IFAC), which has encouraged the adoption of accrual accounting throughout the public sector and has published the IPSAS common standards for public entities from national to local governments (Vivian and Maroun, 2018). At the same time, decentralization reforms and recent global crises have forced LGs to manage their finances more effectively and transparently (Padovani et al., 2021). As a result of these different pressures, it would be reasonable to expect that the use of financial indicators for LG would become more widespread and that some consensus would emerge around indicators universally accepted to assess LG's financial condition.

Financial indicators are part of the wider debate on the adoption of private sector practices in the public sector first promoted by New Public Management (Hood, 1995), which has been 
heavily criticized (Guthrie et al., 2005), but whose ideas, methods and techniques even today remain very influential in public sector daily practices (Hyndman and Liguori, 2016). As such, financial indicators share many of the issues debated over accrual accounting: many scholars maintain that private sector standards and reporting models are inconsistent with the public sector and should be tailored to suit its specific information needs (Adhikari and GarsethNesbakk, 2016).

To further explore these issues, this article develops a structured literature review (SLR), following the methodology proposed by Massaro et al. (2016). A SLR is a type of systematic review, which allows to retrieve and gather publications through a prescribed, replicable and transparent methodology to provide a clear synthesis and appraisal of the extant literature and its main findings on a specific topic (Santis et al., 2018). When compared to other metaanalysis or systematic review logics, SLR is better suited to incorporate findings from contributions that are based on non-experimental protocols or on a limited number of indepth studies (Massaro et al., 2016), such as in public administration accounting and management research (Bracci et al., 2019; Dumay et al., 2015; Garlatti et al., 2020). Moreover, by applying the critical management framework by Alvesson and Deetz (2000), an SLR allows developing insights, critiques and transformative redefinitions, which fit the overall aims of this contribution. Massaro et al. (2016) outline ten steps for developing an SLR, which are described below for this review.

\subsection{Research protocol}

It was identified that there has been no literature review focusing exclusively on LG financial indicators, apart from Hruza (2015) who examined several contributions but fell short of a comprehensive review. Hence, a protocol, including research questions, search methods and analytical framework, was defined anew to make the literature review reproducible and transparent.

2.1.1 Research questions. Given recent LG's accounting reforms and converging pressures, and in line with Alvesson and Detz (2000)'s critical management framework, the questions which stimulated this research were:

(1) How has research on LG's financial indicators developed? Has the literature on financial indicators grown?

(2) What is the focus and critique of the literature on financial indicators? Has consensus developed among scholars on the indicators to be used to assess LG's financial condition? What purpose are they used for? What challenges have arisen?

(3) What is the future of research on financial indicators? What avenues and recommendations have emerged?

2.1.2 Search method. The search strategy was developed through a funnel method, that is it started off with an extensive search with the aim of encompassing all potentially relevant worldwide contributions, followed by a restrictive selection (Santis et al., 2018). Hence, relevant publications were selected through a keyword search in three major databases, that is Scopus, Web of Science and Ebsco (Business Source Complete). Contributions could be any type of academic publication (articles, conference proceedings, books, etc.) without domain or scientific area limitation, but had to be available online in full text in English and should focus on LG indicators derived from financial statements, that is balance sheets, income statements, cash flow statements or any other financial report used for accounting purposes. Hence, contributions dealing with economic, social, environmental or other indicators not derived solely from financial information, did not qualify. On the contrary, contributions using indicators to compare financial performance over time or across different LGs or between

LG financial indicators 
JPBAFM 34,6

budget and actual results were all included in the selection. To avoid missing any relevant publications, the search was then extended to the references included in the selected records.

The keyword search was carried out on June 12th, 2021 and included all relevant publications to that date. In order to be as comprehensive as possible and include all terms used for similar concepts in their singular and plural forms, the search string looked for any publication in English which in its title, keywords or abstract included the words: ("financial" OR "fiscal" OR "budget*") AND ("indicator" or "ratio" or "ratios" or "index" or "indexes" or "indices") AND ("local administration*" or "local authorit*" or "local government*" or "municipal*").

The keyword search returned 3,292 records, of which 1,604 from Scopus, 1,026 from Web of Science and 662 from Ebsco. Once doubles were identified using software and eliminated, 2,101 publications remained. Reading their titles revealed that the keyword search had returned several irrelevant results for LG financial indicators. This is because Scopus, Web of Science and Ebsco cover a broad range of topics from all disciplines and because the adopted keywords were quite extensive. Thus, by eliminating publications with obviously not-pertinent titles, researchers were able to reduce the number of relevant records to 478 . Their abstracts were read by the research team and classified as follows:

(1) Focus on financial indicators for LG;

(2) Simple mention of financial indicators for LG;

(3) Reference only to non-financial indicators for LG or generic issues for LG finances;

(4) No mention of LG financial indicators or issues.

The first two clusters revealed 180 publications which were screened further. Twelve were not available online in full text, mainly being unpublished conference papers and books not available online, and were therefore excluded from further steps in the search procedure. The remaining publications were read entirely and narrowed down to those that focus on financial indicators for LGs. Those that do not deal with financial indicators but focus exclusively on other issues, such as fiscal control, indebtedness, efficiency, accounting standards or a mix of financial and non-financial indicators were discarded. To ensure reliability only those records which all researchers agreed upon were included; this is equivalent to a Krippendorff's $\alpha$ of 1 (Krippendorff, 2013). This step further narrowed down the number of relevant publications to 67 .

At the same time, to limit the risk of over-looking relevant contributions, researchers also checked a further 61 publications mentioned in the records read in full to verify whether they fulfilled the selection criteria. After reading their abstracts, 29 were included in the first two clusters ( 1 = focus on financial indicators for LG; $2=$ simple mention of indicators for LG) and selected. Six of these were not available in full text online. Once they had read the remaining publications, researchers agreed that 12 of them fulfilled the selection criteria and could be included in the analysis.

Therefore, the selection process (Figure 1) led to a total of 79 contributions (identified with * in the "References"), which were deemed relevant and included in the analysis out of the original 2162 publications composed of those retrieved through keyword search (2101) and those from references (61).

\subsection{Literature impact}

The impact of the selected publications, the fourth step in a SLR after defining a research protocol, outlining the research questions and carrying out a literature search, was verified through the pertinence of publication outlets and the impact of selected records on the collective literature. 

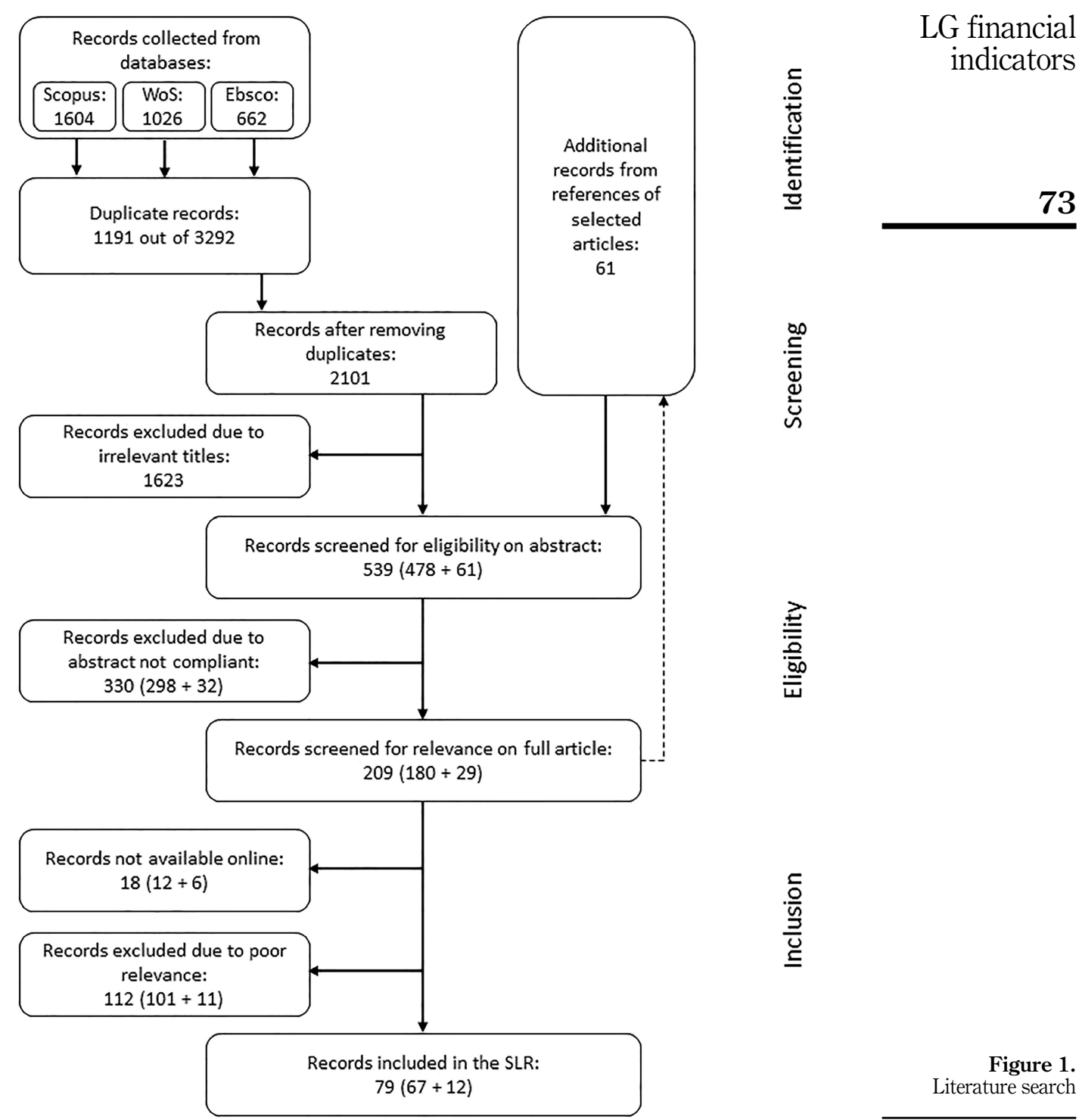

LG financial
indicators

Figure 1. Literature search

Hence, on the one hand, it was verified that, apart from one (Dziekański, 2017), all selected contributions were published in public accounting, administration or management journals, confirming that the topic of LG financial indicators is discussed in relevant academic contexts where it can reasonably have the greatest impact. On the other hand, the number of Google Scholar citations for each record was used as a proxy for their relevance and quality to help appreciate those contributions that have steered the academic debate (Massaro et al., 2016). Table 1 shows the top ten selected publications by number of citations as of June 20th, 2021, and Table 2 shows the top ten records by citations per year, so as to counterbalance the fact 


\begin{tabular}{|c|c|c|c|c|c|c|}
\hline \multirow{3}{*}{$\begin{array}{l}\text { JPBAFM } \\
34,6\end{array}$} & & Author & Title & Publication & Year & Citations \\
\hline & 1 & Brown & $\begin{array}{l}\text { The 10-point test of financial } \\
\text { condition: toward an easy-to-use } \\
\text { assessment tool for smaller cities }\end{array}$ & $\begin{array}{l}\text { Government Finance } \\
\text { Review }\end{array}$ & 1993 & 322 \\
\hline & 2 & $\begin{array}{l}\text { Groves, Godsey, } \\
\text { Shulman }\end{array}$ & $\begin{array}{l}\text { Financial indicators for local } \\
\text { government }\end{array}$ & $\begin{array}{l}\text { Public Budgeting and } \\
\text { Finance }\end{array}$ & 1981 & 254 \\
\hline \multirow[t]{7}{*}{74} & 3 & Zafra-Gómez, López- & Evaluating financial performance & International Review & 2009 & 150 \\
\hline & 4 & $\begin{array}{l}\text { Hernández, } \\
\text { Hernández-Bastida } \\
\text { Rivenbark and } \\
\text { Roenigk }\end{array}$ & $\begin{array}{l}\text { In local government: maxımızing } \\
\text { the benchmarking value } \\
\text { Conceptualizing financial condition } \\
\text { in local government }\end{array}$ & $\begin{array}{l}\text { Public } \\
\text { Administration } \\
\text { Quarterly }\end{array}$ & 2010 & 125 \\
\hline & 5 & $\begin{array}{l}\text { Kloha, Weissert, } \\
\text { Kleine }\end{array}$ & $\begin{array}{l}\text { Someone to watch over me: State } \\
\text { monitoring of local fiscal conditions }\end{array}$ & $\begin{array}{l}\text { American Review of } \\
\text { Public } \\
\text { Administration }\end{array}$ & 2005 & 123 \\
\hline & 6 & $\begin{array}{l}\text { Cabaleiro Casal, } \\
\text { Buch Gómez, } \\
\text { Vaamonde Liste }\end{array}$ & $\begin{array}{l}\text { Developing a method to assessing } \\
\text { the municipal financial health }\end{array}$ & $\begin{array}{l}\text { American Review of } \\
\text { Public } \\
\text { Administration }\end{array}$ & 2012 & 115 \\
\hline & 7 & $\begin{array}{l}\text { Cohen, Doumpos, } \\
\text { Neofytou, } \\
\text { Zopounidis }\end{array}$ & $\begin{array}{l}\text { Assessing financial distress where } \\
\text { bankruptcy is not an option: an } \\
\text { alternative approach for local } \\
\text { municipalities }\end{array}$ & $\begin{array}{l}\text { European Journal of } \\
\text { Operational Research }\end{array}$ & 2012 & 107 \\
\hline & 8 & $\begin{array}{l}\text { Maher and } \\
\text { Nollenberger }\end{array}$ & $\begin{array}{l}\text { Revisiting Ken Brown's 10-point } \\
\text { test" }\end{array}$ & $\begin{array}{l}\text { Government Finance } \\
\text { Review }\end{array}$ & 2009 & 85 \\
\hline & 9 & Carmeli & $\begin{array}{l}\text { A conceptual and practical } \\
\text { framework of measuring } \\
\text { performance of local authorities in } \\
\text { financial terms: analysing the case } \\
\text { of Israel }\end{array}$ & $\begin{array}{l}\text { Local Government } \\
\text { Studies }\end{array}$ & 2002 & 83 \\
\hline $\begin{array}{l}\text { by google scholar } \\
\text { citations (June } \\
\text { 20th 2021) }\end{array}$ & 10 & Cohen & $\begin{array}{l}\text { Identifying the moderator factors } \\
\text { of financial performance in Greek } \\
\text { municipalities }\end{array}$ & $\begin{array}{l}\text { Financial } \\
\text { Accountability and } \\
\text { Management }\end{array}$ & 2008 & 78 \\
\hline
\end{tabular}

that older publications can accumulate more citations, even though they are not necessarily available online and hence could have garnered less exposure.

As evidenced in the tables, five records are common to both rankings: Brown (1993), Cabaleiro Casal et al. (2013), Cohen et al. (2012), Rivenbark and Roenigk (2010), Zafra-Gómez et al. (2009). This indicates that some publications have exerted a more enduring influence on subsequent contributions, have driven the production of new knowledge within the research field and are considered as points of reference regarding financial indicators. Indeed, they include some of the older publications on financial indicators, such as Groves et al. (1981) and Brown (1993), which have been praised for their simplicity, as they use data easily accessible from financial reports (Maher and Nollenberger, 2009), so much that they have become seminal contributions, as discussed in more detail in Section "3.2.1.1 Proposed dimensions and indicators". Yet, taking into consideration the citations per year statistics (Table 2), more recent publications (Gorina et al., 2018; Bisogno et al., 2019) are also highly cited, confirming the on-going relevance of the topic and importance of its current developments.

\subsection{Analytical framework}

Wherever possible the dimensions around which contributions were analyzed and classified were developed using schemes used for other SLRs (Bracci et al., 2019; Dumay et al., 2015; Manes Rossi et al., 2020). Researchers first read the seven most cited records, that is $10 \%$ of 


\begin{tabular}{|c|c|c|c|c|c|c|}
\hline & Author & Title & Publication & Year & $\mathrm{CPY}$ & s financis \\
\hline 1 & Gorina $e t a l$. & $\begin{array}{l}\text { Local fiscal distress: Measurement } \\
\text { and prediction }\end{array}$ & $\begin{array}{l}\text { Public Budgeting and } \\
\text { Finance }\end{array}$ & 2018 & 19.33 & \\
\hline 2 & Bisogno et al. & $\begin{array}{l}\text { Budgetary solvency of Italian local } \\
\text { governments: an assessment }\end{array}$ & $\begin{array}{l}\text { International Journal of } \\
\text { Public Sector } \\
\text { Management }\end{array}$ & 2019 & 14.50 & \\
\hline 3 & $\begin{array}{l}\text { Cabaleiro } \\
\text { Casal et al. }\end{array}$ & $\begin{array}{l}\text { Developing a method to assessing the } \\
\text { municipal financial health }\end{array}$ & $\begin{array}{l}\text { American Review of } \\
\text { Public Administration }\end{array}$ & 2012,2013 & 14.38 & 75 \\
\hline 4 & $\begin{array}{l}\text { Navarro- } \\
\text { Galera } \text { et al. }\end{array}$ & $\begin{array}{l}\text { Measuring the financial sustainability } \\
\text { and its influential factors in local } \\
\text { governments }\end{array}$ & Applied Economics & 2016 & 13.20 & \\
\hline 5 & $\begin{array}{l}\text { Zafra-Gómez } \\
\text { et al. }\end{array}$ & $\begin{array}{l}\text { Evaluating financial performance in } \\
\text { local government: Maximizing the } \\
\text { benchmarking value }\end{array}$ & $\begin{array}{l}\text { International Review of } \\
\text { Admin. Sciences }\end{array}$ & 2009 & 12.50 & \\
\hline 6 & Cohen et al. & $\begin{array}{l}\text { Assessing financial distress where } \\
\text { bankruptcy is not an option: An } \\
\text { alternative approach for local } \\
\text { municipalities }\end{array}$ & $\begin{array}{l}\text { European Journal of } \\
\text { Operational Research }\end{array}$ & 2012 & 11.89 & \\
\hline 7 & Brown & $\begin{array}{l}\text { The 10-point test of financial } \\
\text { condition: Toward an easy-to-use } \\
\text { assessment tool for smaller cities }\end{array}$ & $\begin{array}{l}\text { Government Finance } \\
\text { Review }\end{array}$ & 1993 & 11.50 & \\
\hline 8 & $\begin{array}{l}\text { Rivenbark } \\
\text { et al. }\end{array}$ & $\begin{array}{l}\text { Conceptualizing financial condition in } \\
\text { local government }\end{array}$ & $\begin{array}{l}\text { Public Administration } \\
\text { Quarterly }\end{array}$ & 2010 & 11.36 & \\
\hline 9 & Dziekański & $\begin{array}{l}\text { Diversification synthetic indicator for } \\
\text { evaluating the financial capacity of } \\
\text { local government. the case of Polish } \\
\text { voivodeships }\end{array}$ & Acta Universitatis & 2017 & 11.25 & $\begin{array}{r}\text { Table } 2 . \\
\text { Top ten publications } \\
\text { by google scholar }\end{array}$ \\
\hline 10 & Turley et al. & $\begin{array}{l}\text { A framework to measure the financial } \\
\text { performance of local governments }\end{array}$ & $\begin{array}{l}\text { Local Government } \\
\text { Studies }\end{array}$ & 2015 & 10.83 & $\begin{array}{r}\text { citations per year (CPY, } \\
\text { June 20th 2021) }\end{array}$ \\
\hline
\end{tabular}

the selected publications, and then discussed the appropriateness of the frameworks from other SLRs. They were adapted them to obtain a framework that was coherent with the research objectives and peculiarities of this SLR.

The final framework, which is summarized in Tables 3 and 4, was organized around four clusters of analysis and thirteen categories:

(1) Research timeframe to explore the literature development over time; consistently with previous SLRs, the only category included was the year of publication;

(2) Research design to understand how research on financial indicators has developed; three categories were included. Two were taken and adapted from previous research (Bracci et al., 2019; Dumay et al., 2015; Manes Rossi et al., 2020), that is the research method employed and whether existing models were used, while the third category in this cluster, "Orientation", was developed as a new category to help appreciate whether publications discussed financial indicators or simply applied an existing model without any discussion, which would indicate the level of acceptance of a particular model;

(3) Research context to appreciate what the literature has covered and which settings are yet to be explored: as in Bracci et al. (2019) two categories were included, that is "geographical focus" and "jurisdiction". This allowed to appreciate both the specific country or countries the publications focused on and whether the scope of the research was local including only one LG, regional if it covered LGs from one region, 
JPBAFM

34,6

\begin{tabular}{ll}
\hline & Publicat \\
\hline (a) Year of publication & \\
$1977-1989$ & \\
$1990-1999$ & \\
$2000-2009$ & \\
$2010-2014$ & \\
$2015-2019$ & \\
$2020-$ & \\
Total &
\end{tabular}

$\%$

(b) Research methods

Case/Field study/Interviews

Content analysis/Historical analysis

Survey with questionnaire

Empirical comparisons

Statistical modelling for financial issues

$5.1 \%$

Statistical modelling for indicator selection

Commentary/Normative/Policy

Literature review

Mixed methods

Total

(c) Orientation

Discussion/assessment of financial indicator models $100.0 \%$

Straightforward application of existing indicators Total

$75.9 \%$

(d) Model used

Application/consideration of existing models

Proposal of new sets of indicators

Refinement/integration of existing models

Total

(e) Geographical focus

USA

Spain

Poland

Indonesia

Italy

More countries

Slovakia

Australia

Czech Republic

Ireland

China

Greece

New Zealand

UK

Other country

Total

$21.5 \%$

$11.4 \%$

$8.9 \%$

$7.6 \%$

$6.3 \%$

$6.3 \%$

$5.1 \%$

$3.8 \%$

$3.8 \%$

$3.8 \%$

$2.5 \%$

$2.5 \%$

$2.5 \%$

$2.5 \%$

$11.4 \%$

(f) Jurisdiction

$100.0 \%$

Table 3.

Research timeframe, design and context
International

National

State/provincial/regional

Local

Total
$6.3 \%$ $59.5 \%$

$24.1 \%$

$10.1 \%$ $100.0 \%$ 


\begin{tabular}{|c|c|c|c|}
\hline & Publications & $\%$ & LG financial \\
\hline \multicolumn{4}{|l|}{ (a) Data source } \\
\hline Income statement, balance sheet & 49 & $62.0 \%$ & \\
\hline Cash statement, income statement, balance sheet & 17 & $21.5 \%$ & \\
\hline Cash statement & 8 & $10.1 \%$ & \\
\hline Balance sheet & 3 & $3.8 \%$ & \\
\hline Income statement & 1 & $1.3 \%$ & 77 \\
\hline \multirow{2}{*}{$\begin{array}{l}\text { Cash statement, income statement } \\
\text { Total }\end{array}$} & 1 & $1.3 \%$ & \\
\hline & 79 & $100.0 \%$ & \\
\hline \multicolumn{4}{|l|}{ (b) Accounting system } \\
\hline Cash & 3 & $3.8 \%$ & \\
\hline Modified cash & 2 & $2.5 \%$ & \\
\hline Accrual & 11 & $13.9 \%$ & \\
\hline Mixed & 11 & $13.9 \%$ & \\
\hline Not indicated & 52 & $65.8 \%$ & \\
\hline Total & 79 & $100.0 \%$ & \\
\hline \multicolumn{4}{|l|}{ (c) Model origin } \\
\hline Groves et al. (1981)/ICMA & 18 & $22.8 \%$ & \\
\hline CICA (2009) & 5 & $6.3 \%$ & \\
\hline ICMA and CICA (2009) & 9 & $11.4 \%$ & \\
\hline Other & 47 & $59.5 \%$ & \\
\hline Total & 79 & $100.0 \%$ & \\
\hline \multicolumn{4}{|l|}{ (d) Liquidity and solvency (multiple answers possible) } \\
\hline Long term solvency & 55 & $69.6 \%$ & \\
\hline Budgetary solvency & 35 & $44.3 \%$ & \\
\hline Short term solvency & 26 & $32.9 \%$ & \\
\hline Liquidity & 24 & $30.4 \%$ & \\
\hline None & 12 & $15.2 \%$ & \\
\hline Number of articles included-Answers \% & 79 & $192.4 \%$ & \\
\hline \multicolumn{4}{|l|}{ (e) Use of composite measure/index } \\
\hline Multiple indicators with composite measure/index & 11 & $13.9 \%$ & \\
\hline Multiple indicators without composite measure/index & 68 & $86.1 \%$ & \\
\hline Total & 79 & $100.0 \%$ & \\
\hline \multicolumn{4}{|l|}{ (f) Purpose for using indicators (multiple answers possible) } \\
\hline Compliance re. transparency and accountability & 12 & $15.2 \%$ & \\
\hline Monitoring and benchmarking performance & 11 & $13.9 \%$ & \\
\hline Assessing financial health & 63 & $79.7 \%$ & \\
\hline Dealing with exogenous crises & 11 & $13.9 \%$ & Table 4. \\
\hline Number of articles included-Answers \% & 79 & $122.8 \%$ & Research focus \\
\hline
\end{tabular}

province or state, national if it focused on the LGs of one country or international if it considered LGs across countries;

(4) Research focus to investigate the core issues and limitations of the extant literature. This cluster was dedicated to issues peculiar to financial indicators and included seven categories specifically developed for this SLR (Table 4), that is: "Data source", which is the accounting source used to calculate financial indicators; "Accounting system", which indicates the accounting system in use specified in the publications; "Model origin", to highlight whether the publications refer to the most cited models, if any; "Liquidity and solvency", to verify whether the publications include such indicators; "Use of composite measure or index", which highlights whether 
JPBAFM 34,6

\section{8}

publications develop a single index from multiple indicators; "Purpose for using indicators", which helps appreciate what indicators are used for; and lastly "Issues and challenges", which reports concerns with indicators which emerged from each publication, but could not be meaningfully represented in tabular format as arguments were too varied and hence were analyzed in the "Concerns about financial indicators" Section (3.2.2).

\subsection{Reliability, coding and validity}

Reliability in recording and analyzing data was ensured through several methods (Massaro et al., 2016), that is by selecting dimensions and categories from well-grounded relevant literature, and by establishing a reliable coding instrument with well-specified decision categories and decision rules. Researchers initially independently coded the seven most cited records to determine the reliability of the adopted framework and clarify any discrepancies.

Validity was pursued using different tactics. Internal validity, which seeks to establish causal relationships, was ensured through "pattern matching" and "explanation building" (Yin, 2014), that is starting to develop some appreciations from the most cited papers and then enlarging the sample to test the initial implications (Massaro et al., 2016). In other words. the results were both checked first through rival explanations, logic models and triangulation within a small group of articles and then confirmed enlarging the analysis to the whole data set, comparing number of articles and their citation impact (Yin, 2014). External validity, which concerns the generalizability of results, that is in how far the selected articles can be considered representative of the available literature, was safeguarded by the initial extensive search and by verifying that findings could be explained by theory or previous studies (Massaro et al., 2016; Yin, 2014). Construct validity, that is to ensure that appropriate operational measures are established for the concepts under research, was pursued by using multiple sources to support results (Massaro et al., 2016), including publications which were excluded from the literature search because, for example, they dealt with mixed indicators. It was important to appreciate argumentations from scholars who looked at other indicators and appraised the benefits and the limitations of working with financial ones (Caruana et al., 2019; Hendrick, 2004).

\section{Results}

\subsection{Insights: the financial indicators literature}

Examining the selected literature reveals that the research on financial indicators is vibrant, yet still focused on the local and national levels with little international outlook, comparisons or convergence (Table 3 ).

3.1.1 Research timeframe. Among the selected literature, the first record was published in 1977 (Petersen, 1977), while most contributions appeared in the last decade (over 80\%, Table 3 (a), and particularly between 2015 and 2019 (48\%). This is probably due to the interest in financial indicators brought about by the 2008 financial crisis and the adoption of accrual accounting and IPSAS in many countries since the turn of the century. This provides an initial partial answer to the first research question: financial indicators have indeed become more popular over time. However, over the past couple of years publications focusing on LG financial indicators seem to have dropped off (Figure 2). Hence, it will be important to monitor future publications to understand whether this is a short-lived (and possibly pandemic induced) anomaly or whether research has moved on to other tools, beyond financial indicators, to analyze LG's financial condition.

3.1.2 Research design. Research design helps assess the prevalence of some methods and the level of theoretical sophistication, that is whether contributions develop new models 


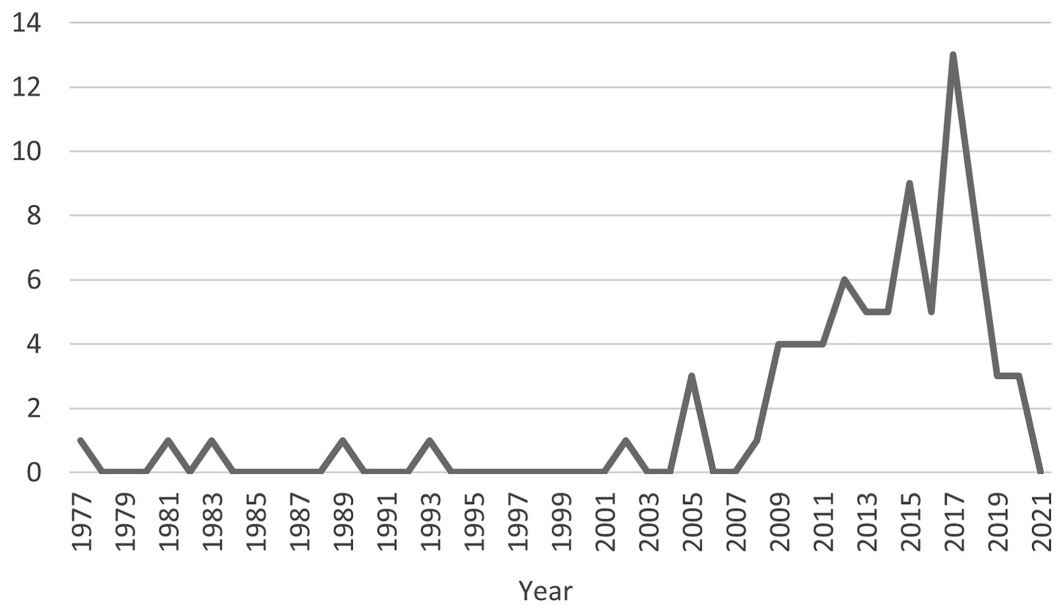

rather than applying or attempting to refine existing ones. This allows appreciating what characterizes research on financial indicators and whether there is a risk of "under-theorized empirics", that is empirical studies with no theoretical basis, or of "armchair theorizing", that is theoretical conceptualizations with no empirical backing. The latter could then end up in "disembedded theory" with little, if any, supporting evidence (Bracci et al., 2019).

Most of the selected publications ( 64 out of 72 , Table $3 \mathrm{~b}$ ) use an empirical and quantitative research method, collecting data from LGs and testing their hypotheses about financial indicators. Many studies (33, Table $3 \mathrm{~b}$ ) rely on comparing indicators calculated from financial reports to compare financial condition over time (for example, Atan et al., 2010), across different LGs (Brown, 1993) or between types of local entities (Carini and Teodori, 2019; Carmeli, 2002). In 18 publications statistical modelling was used to investigate financial issues such as budgetary solvency (Bisogno et al., 2019), financial performance (Cohen, 2008), financial risk and distress (García-Sánchez et al., 2012; Murray and Dollery, 2005; Trussel and Patrick, 2013, 2018) or the interest rate charged to LGs (Bastida et al., 2014). In 11 publications statistical modelling was used to test the validity of a model (Pridgen and Wilder, 2013) or construct indexes from financial indicators (Cabaleiro Casal et al., 2012), while only two publications collected data through an ad hoc questionnaire to assess which indicators are used and for what purpose (Kloha et al., 2005; Susanto and Djuminah, 2015).

With such a preponderance of empirical methods, there is no risk of "armchair theorizing", but rather of "under-theorized empirics" (Bracci et al., 2019), because of a "dominant approach of pragmatic empiricism" (Hruza, 2015). This has an impact on the theoretical sophistication of the selected records: over $75 \%$ of them discuss which models to use, their advantages and drawbacks and almost $40 \%$ of them propose new sets of indicators rather than applying or refining existing ones (Table $3 \mathrm{c}$ and d). This speaks against the hypothesis that global financial crises and pressures towards common accounting standards would lead to the emergence of more universally accepted financial indicators for LGs.

3.1.3 Research context. Over half of the selected publications focus their research on Western countries, which is not surprising as these were the first countries to adopt accrual accounting and IPSAS or to have implemented public sector accounting reforms in that direction (Manes Rossi et al., 2016). The rest of the records look at a diverse group of countries from Eastern Europe and Asia, such as Poland and Indonesia, where accrual accounting has recently been introduced at LG level.
LG financial indicators

Figure 2. Publications by year 
JPBAFM 34,6

80
What is more surprising is that most research on financial indicators for LGs does not draw comparisons across countries. Only five contributions (Citro et al., 2018; De Matteis and Preite, 2018; Hegedüs and Lentner, 2020; Hruza, 2015; Padovani et al., 2018) look at LGs in more than one country, while all other selected publications focus on analyses at national, provincial or solely local level (Table $3 \mathrm{f}$ ). Hence, notwithstanding the adoption of accruals and IPSAS, common financial indicators for LGs are just beginning to emerge, meaning international comparative studies are still difficult to conduct (Carmeli, 2002). This is particularly striking for the EU countries where a harmonization process has been in place since EU Directive 85/2011 and the Fiscal Stability Treaty came into effect on January 1st, 2013.

\subsection{Critical reflections: focusing on LG financial indicators}

A critical analysis of the literature (Table 4) reveals that a plethora of indicators has been developed since they depend not only on the country they are applied to (Carmeli, 2002), but also on the accounting standards and data available (Cohen, 2008; Hruza, 2015; Rivenbark and Roenigk, 2011; Robbins et al., 2016; Winarna et al., 2017), on the reasons for using such tools (Petersen, 1977) and on potential users such as supervisory bodies, liability holders and citizens (Atan et al., 2010; Cohen et al., 2017; Padovani et al., 2018). However, some consensus is emerging on the dimensions to be used when assessing LG's financial condition, but many concerns remain to be addressed.

3.2.1 Research focus. The indicators used in most of the selected publications use information from income statements and balance sheets (62\%, Table 4a), confirming the initial hunch that accrual accounting is key to the development of financial indicators. Indeed, income statements and balance sheets report information that show resource consumption for public services and activities which traditional cash-based accounting systems do not contemplate (Ozkul and Alkan, 2017). However, using a balance sheet as a data source does not automatically imply that the accounting system in use is accrual-based; as a matter of fact, a balance sheet could be included in the financial statement, although the accounting system adopted by public sector entities is cash- or modified-cash based.

Therefore, the accounting system in use was investigated. It is interesting to notice that while some scholars (Cohen, 2008; Hruza, 2015; Rivenbark and Roenigk, 2011) recognize the fact that which financial indicators can be used to assess LG's condition depends on the accounting system in place, only a third of publications explicitly report it (34\%, Table 4b). Whether it is implied or assumed to be known, it is also true that in many countries LG accounts rely on a set of competing or multiple logics with different accounting systems coexisting at LG level (Manes Rossi et al., 2016).

3.2.1.1 Proposed dimensions and indicators. The selected literature confirms that financial performance measures and assessments require multi-dimensional, multi-indicator approaches (Carini and Teodori, 2019; Clark, 2015). As expected, no publication included in this literature review suggests using only one indicator to assess LG's condition.

The analysis highlighted two main models which many authors refer to (Table 4c), namely the one proposed by Groves et al. (1981) and the indicators developed by the Canadian Institute of Chartered Accountants (CICA, 2009). The former model (Groves et al., 1981) focuses on solvency and considers four dimensions: short-term liquidity, budgetary solvency, long-run solvency and service level solvency. Its indicators were adopted by the American Financial Trend Monitoring System (FTMS), released by the International City/County Management Association (ICMA) to propose an internal monitoring system for US LGs (Cabaleiro Casal et al., 2013). Yet, only Stevens and McGowan (1983) use the same set of indicators as Groves et al. (1981). All other publications who apply their model refer to the same dimensions but use a selection of different indicators. 
The other key model (CICA, 2009) sought to provide a common methodology for assessing the financial condition of Canadian LGs, which was defined as their ability to meet existing financial obligations, including both service commitments to residents and financial commitments to creditors and employees. Financial condition is analyzed through three dimensions: sustainability, flexibility and vulnerability. Sustainability refers to whether an organization can maintain its programs, while complying with credit requirements, without increasing the level of its indebtedness. Flexibility is the degree to which an organization can increase its financial resources to respond to rising commitments, whether by increasing its revenues or its debt. Finally, vulnerability is the extent to which an organization depends on resources beyond its own control.

The relationship between the dimensions of the two models is not universally accepted. Some authors (Zafra-Gómez et al., 2009) maintain that the level of sustainability, flexibility and vulnerability measure budgetary solvency, which is understood as LG's ability to generate enough income to pay for expenses and not incur a deficit. Conversely, other authors (Cabaleiro Casal et al., 2012) find aspects of the dimensions of sustainability and flexibility included in long-run solvency, while budgetary solvency contains vulnerability, along with some aspects that are associated with flexibility, and service-level solvency includes other aspects of flexibility.

However, the same critical issue applies to the contributions which adopt either model: while there is convergence on the dimensions to assess LG's financial condition, different indicators are used. At one extreme, Cabaleiro Casal and Buch Gómez (2011) proposed 34 indicators to assess the financial health of Spanish municipalities, while Cohen et al. (2012) selected only six indicators to analyze the financial distress of Greek local administrations.

Regardless of the model they refer to, many publications share a balance between a short-term perspective and a long-term perspective with liquidity and solvency as the most cited dimensions (Table 4d). Liquidity measures a LG's ability to pay current liabilities. It is often operationalized using the ratio of cash and other liquid assets to short term liabilities as in a "quick ratio" or "acid test" (Hughes and Katwal, 2011), but some authors intend it as cash or short-term solvency, that is the ratio between all current assets and short-term liabilities (Cohen, 2008). Over half of the publications refer to either liquidity or short-term solvency $(63 \%)$, as these concepts often blur together and depend on the different accounting information used (cash or accrual). On the other hand, most authors (55 out of $79,70 \%$ ) refer to long-term solvency, that is the debt repayment capacity or the impact of existing long-term obligations on future resources. Long-term solvency is also measured using different ratios: total liabilities to net assets (Hughes and Katwal, 2011), total liabilities to total assets (Pridgen and Wilder, 2013; Wojtasiak-Terech and Makowska, 2017), long-term debt to long-term assets (Kazlauskiene and Aidukiene, 2014), debt service to total revenue (Brown, 1993; Greganova et al., 2015) or a combination of them. The same is true for budgetary solvency which is dealt with in a little under half of the selected literature (44\%), but is measured by different indices such as the ratio between total revenues and total expenditures (Cabaleiro Casal and Buch Gómez, 2014), or the ratio between total revenues except transfers and total expenditures (García-Sánchez et al., 2012; Liuta et al., 2015), or the ratio between the difference of total revenues and total expenditures over total revenues (Stevens and McGowan, 1983).

Hence, there is some consensus on using long-term solvency, liquidity/short-term solvency and budgetary solvency to assess LG's financial condition, but not on the indicators to be used to measure such dimensions (Hruza, 2015; Wojtasiak-Terech and Makowska, 2017).

Lastly, eleven publications calculate a composite index to allow more immediate comparisons and a quicker assessment of LG's condition (Table 4e). It should also be noted that half of such publications wish to investigate LGs in financial distress and that they focus on budgetary solvency, but that no clear reference to other dimensions emerges. Moreover,

LG financial indicators 
JPBAFM 34,6

the same authors proposing such synthetic measures highlight two major drawbacks: on the one hand, public managers and elected officials need anyway to examine the financial condition of their cities across multiple dimensions to understand it (Clark, 2015). On the other hand, the problems related to single indicators are not solved, on the contrary they are often magnified in a composite measure that gives the illusion of making comparing LG's condition easier (Cabaleiro Casal et al., 2013; Dziekański, 2013; Mahbub et al., 2017; Natrini and Ritonga, 2017). Thus, for example, rating agencies offer credit rating models that are a compromise between a single score and a vast variety of indicators (Gorina et al., 2018).

3.2.1.2 Benefits and purposes of using indicators. One of the reasons why so many indicators are present in the selected literature is because they can be used to satisfy different purposes (Petersen, 1977). The reasons for using such indicators can be grouped into four main categories (Table $4 \mathrm{f})$. In most of the selected literature $(80 \%)$ indicators are used to assess financial health and can play a central role for the provision of information useful for decision making to enable better control of the budgetary process (Bisogno et al., 2019; Papcunova et al., 2015; Zafra-Gómez et al., 2009). Yet, there is considerable ambiguity about what constitutes financial difficulties and how to recognize them before they become emergencies (Kloha et al., 2005; Sebestova et al., 2018b; Trussel and Patrick, 2013). Looking specifically at those 48 publications which cite only "assessing financial health" among the purposes for using indicators, they make more often use of solvency indicators than the overall sample, and, in particular, of long-term solvency: $81 \%$ refer to long-term solvency (against $70 \%$ in the overall sample), $52 \%$ to budgetary solvency (against $44 \%$ ) and $42 \%$ to short-term solvency (against 33\%). Hence, in most of the selected literature financial health tends to be assessed using solvency and, especially, long-term solvency.

Secondly, in countries such as Australia (Pilcher, 2005), the UK (Hepworth, 1989), Spain (Bastida et al., 2014), Poland (Dziekański, 2016; Grzebyk, 2012) and Indonesia (Fafurida and Pratiwi, 2017; Susanto and Djuminah, 2015) indicators are also used for compliance regarding transparency and accountability disclosure. This is a rather complex issue which is often country specific and difficult to deal with in an overall analysis like this one for its many nuances. For example, Steccolini et al. (2020) refer to compliance induced by "coercive pressures", when comparisons are made with a set of performance standards decided upon by central governments, or "normative pressures", when standards are recommended by professional organizations.

Moreover, a small but growing literature is also devoted to benchmarking LG's performance (Robbins et al., 2016) and examining how such comparisons affect outcomes (Gerrish and Spreen, 2017; Turley et al., 2015). Beyond helping managers compare financial performance across jurisdictions, stakeholders such as rating agencies, investors and even private citizens can use financial indicators to compare LG performance and decide whether to invest there (Padovani et al., 2018; Zafra-Gómez et al., 2009; Zarska and Rafaj, 2016), which Steccolini et al. (2020) refer to as "mimetic pressures". In general, the use of financial performance for benchmarking purposes holds both promises and perils: on the one hand, administrators and stakeholders have new tools with which to compare jurisdictions, on the other, it is feared that organizations may take actions that improve reported performance, but may leave actual performance unchanged (Turley et al., 2015). Even worse, in their study of municipalities in North Carolina, Gerrish and Spreen (2017) concluded that introducing financial ratios for benchmarking purposes created isomorphic pressures even among the best performers to converge towards the target performance rather than exceeding it.

Lastly, following the 2008 financial crisis some authors have proposed to use financial indicators to help weather exogenous shocks (Hruza, 2015). Indicators help provide early signals of external financial distress affecting local finances (Cohen et al., 2017; García-Sánchez et al., 2012) and they can monitor the presence of a system of adequate 
coping capacities such as financial reserves, limited rigid expenditures and low debt levels (Dziekański, 2013; Greganova et al., 2015; Zarska and Rafaj, 2016).

Therefore, the main purpose for using financial indicators for LGs is to assess their financial health retrospectively and meeting compliance requirements. However, two more forward-looking benefits have emerged from the more recent literature: using financial indicators for benchmarking purposes and coping with financial shocks. This may become particularly relevant in the aftermath of the Covid-19 epidemic.

3.2.2 Concerns about financial indicators. The literature review has highlighted three main constraints in using financial indicators: a lack of clear definitions for key concepts, accounting standards which make it difficult to produce meaningful synthetic measures and limitations relative to using purely financial indicators.

3.2.2.1 Malleable definitions. The array of indicators that has been developed is not only the result of different methodological approaches, purposes and contexts, but also of a great ambiguity in terminology (Cabaleiro Casal et al., 2012; Ritonga, 2014). The lack of clear definitions regarding some basic financial concepts means that they are sometimes used interchangeably (Cabaleiro Casal et al., 2013). Even the concept of financial condition does not have a universal appreciation in the literature (Brusca et al., 2018), because it is difficult to represent it since it changes over time and it depends on the appreciation of the objectives of a public entity (Citro et al., 2018). Groves et al. (1981) meant financial condition as solvency, differentiating between short, medium and long-term solvency, that is the ability of a LG to fulfil its various obligations (Ritonga et al., 2012). Over time, scholars started talking interchangeably about financial condition, financial health and financial sustainability, even though they are neither understood nor operationalized in the same way and suffer from various conceptualizations. Most authors understand financial health as the absence of distress, meaning an imbalance between revenue capacity and expenditure needs, which though for some is related solely to risk and debt management (Kluza, 2017a, b; Pridgen and Wilder, 2013; Yi, 2009), while others pinpoint to short-term considerations, namely a LG's ability to meet its payroll on time (Manes Rossi et al., 2012), while for others it corresponds to service delivery and adhering to minimum quality standards (Winarna et al., 2017), and for yet others it refers to a combinations of these issues (Murray and Dollery, 2005; Padovani et al., 2018; Trussel and Patrick, 2018). Other scholars include in a healthy financial condition also the ability of LGs to deal with events that are unexpected in the impending future, such as natural or social disasters (Ritonga, 2014).

As far as financial sustainability is concerned, there is agreement among authors that it should consider both budgetary solvency and the maintenance of satisfactory liquidity, but there is no agreement about whether to include service level and to what extent (Caruana et al., 2019; Manes Rossi et al., 2017).

If just analyzing one concept has revealed how malleable definitions can be, some scholars wonder how different definitions of financial condition and other constructs can then be measured through the same or similar indicators (Natrini and Ritonga, 2017).

3.2.2.2 Unsuitable accounting standards. Some authors note that accounting standards are not always suited to LGs and this diminishes the relevance of financial indicators in assessing LG's financial condition (Drew and Dollery, 2014; Pilcher, 2005). The issues at stake are twofold: the type of accounting standards used and the limitations intrinsic to public accounting.

On the one hand, despite efforts by standard setting authorities to encourage the use of accrual accounting, many LGs continue to prepare their financial statements on a cash or modified-cash basis (Padovani et al., 2018; Susanto and Djuminah, 2015). Yet, if a municipality has not adopted accrual accounting, its financial condition can only be measured partially. Factors such as the economic life of its assets as well as liabilities for pensions and other post-retirement benefits are likely to be under reported or missing altogether.
LG financial indicators 
JPBAFM 34,6

84

On the other hand, even with accrual accounting, certain standards are only partially suitable for public sector organizations. Private sector accounting relies heavily on concepts and measurements derived from fair value accounting and the balance sheet approach. Yet, the absence of a market in the provision of many public goods and services causes significant consequences concerning the definition, valuation, classification, depreciation and presentation of public assets and liabilities, as well as issues of capital maintenance and erosion (Lapsley et al., 2009). Differently from private assets, public goods such as public monuments, heritage assets, infrastructure assets and community assets, seldom have any liquid markets and tractable market values and they benefit the public at large and not only the public entity which owns them (Oulasvirta, 2014). Similarly, there are no standards to account for returns on public sector assets or depreciation (Hruza, 2015). Hence, money values assigned to public assets are typically arbitrary and unreliable, so that valuation and depreciation result in questionable financial figures that distort the reported "bottom line" of municipalities (Pilcher, 2005).

Furthermore, debt management in the public sector is different from private entities, due to the possibility of many LGs to raise revenue through taxes, receive additional funding from central governments when in distress, and the redistributive role they play in managing the economy (Caruana et al., 2019). The representation of liabilities in the balance sheet of a LG may be misleading (Kluza, 2017a). In fact, a negative asset balance does not necessarily deter potential investors from investing in a public entity's debt (Caruana et al., 2019). Thus, a LG with a lower debt level and a higher long-term solvency ratio does not necessarily have a better risk profile than a more indebted one with a lower long-term solvency index.

From discussing the adoption of accrual accounting by the public sector, two considerations emerge. On the one hand, the few authors (Bătrâncea et al., 2013; Cohen, 2008; Mustafin et al., 2017; Winarna et al., 2017) who have promoted the application of typical profitability ratios from the private sector, such as return-on-equity (ROE), return-on-assets (ROA) and return-on-investment (ROI), have also verified that the assessment of financial performance through such ratios can reveal to be inaccurate and even meaningless (Cohen, 2008). On the other hand, some authors suggest that LG's balance sheet and income statements should be redesigned to better represent the specific working of public finances (Cohen et al., 2012; Pilcher, 2005), reinforcing that private standards ill suit LGs and that new principles should be developed.

3.2.2.3 Limitations of financial indicators. The selected literature highlights several limitations in working with financial indicators related to the incompleteness of purely financial information, its reliability, its comparability in different context and the impact of external factors.

First of all, financial LG's condition can only be partially evaluated by examining their financial position, financial performance and cash flows (Caruana et al., 2019). Unlike the rather straightforward evaluation of the financial condition of a business entity based on the analysis of its profitability by means of well-understood financial ratios, such an evaluation for public sector entities involves judgments about the interplay of complex social, organizational and financial factors (Cohen, 2008; De Matteis and Preite, 2018; Walker and Andrews, 2015). On the one hand, public sector organizations have long term aims which may not be revealed by the analysis of yearly indicators (Carmeli, 2002; Hruza, 2015). On the other hand, while some scholars call for parsimonious tools for analyzing LG's condition (Maher et al., 2020), purely financial data do not always tell the complete story about LG's condition, since they fail to measure factors such as economic wealth, policy, service levels, quality and effectiveness with respect to specific users and a variety of other intangible elements that are important for accountability (Carmeli, 2002; Robbins et al., 2016; Zafra-Gómez et al., 2009).

Secondly, the wide array of indicators present in the literature and used in practice has determined a diversity of measurements by different authorities (Zafra-Gómez et al., 2009) 
and of approaches to LG's financial assessment by supervisory bodies (Padovani et al., 2018). The concern here is twofold: on the one hand, it is feared that the quality of the data collected is not good enough (Pilcher, 2005), on the other hand, Petersen (1977) noted that financial information is often of little use because it is frequently late, hard to obtain and seldom uniform. Moreover, while relying on a set of audited financial statements to assess a municipality's financial condition may mitigate the risk of poor information quality (Cohen et al.,2012), it could also be dangerous, because audited financial statements only verify that a LG has followed mandatory accounting standards, not that such standards are appropriate for assessing financial condition (Drew and Dollery, 2014; Hruza, 2015; Padovani et al., 2018).

Thirdly, financial management is not a one-size-fits-all exercise (Manes Rossi et al., 2017). Some authors maintain that measuring and controlling financial condition cannot be done in the same way regardless of size and governance setting. On the one hand, Carini and Teodori (2019), Navarro-Galera et al. (2016) and Modlin (2010) noticed that their analysis could only be limited to the largest municipalities in Italy, Spain and North Carolina respectively, because, for example, size may influence the variety of services offered by LGs and their financing approaches (Cabaleiro Casal and Buch Gómez, 2011; Turley et al., 2020; Zarska and Rafaj, 2016). On the other hand, the selected literature revealed that financial indicators are not sufficient when the prevailing model of governance differs from direct provision (Manes Rossi et al., 2017). At a minimum, consolidated financial statements covering also outsourced services and activities are needed to give an overall, coordinated view of a LG's financial condition (Carini and Teodori, 2019).

Lastly, some scholars maintain that financial ratios are not flexible enough to account for the impact of factors that are external to local authorities and outside their decision-making perimeter (Arunachalam et al., 2016, 2017; Hruza, 2015; Ritonga, 2014).

The above constitute the main threats related to using financial indicators which have emerged from the literature, yet they do not undermine the benefits of using them, but rather warn for caution.

\section{Discussion: future developments and research}

This SLR has offered some answers to the initial research questions. First of all, it has revealed that the literature focusing on LG's financial indicators has grown over time, particularly since the 2008 financial crisis and notwithstanding the very recent drop in publications. Yet, no real consensus has emerged among scholars on the indicators to be used to assess LG's financial condition, even though some convergence has emerged in using some measures of liquidity and solvency.

Second, this review has highlighted that financial indicators are used for four main purposes: transparency and accountability compliance, performance monitoring and benchmarking, assessing LG's financial health and helping weather exogenous crises. Moreover, it has emerged that most indicators are calculated using information from income statements and balance sheets, confirming that accrual accounting plays a role in the development of financial indicators, even though it was not possible to appreciate how strong the connection between the use of LG financial indicators and the implementation of accrual or IPSAS is, since no clear reference is made in most publications to the accounting system in use and in many countries multiple accounting systems coexist at LG level.

Lastly, many criticisms have been raised about LG financial indicators themselves. Several authors warn that they may misinform as much as they inform, if users are unaware of their limitations (Pilcher, 2005). On the one hand, there is the basic skepticism about applying them to LGs because accounting information, even if detailed in nature, offers only a limited understanding of the complexity of LGs (Robbins et al., 2016). On the other hand, there are substantial issues which need to be addressed if financial indicators are to be used

LG financial indicators 
JPBAFM 34,6

effectively to assess LG's financial condition. In particular, some scholars question the integrity of different public sector indicators as their robustness and accuracy rely not only on definitions, which are not unanimously accepted, but also on the accuracy and robustness of the information upon which they are calculated, which is not always suitable to the public sector, let alone available or verifiable (Cabaleiro Casal et al., 2013; Padovani et al., 2018; Pilcher, 2005; Robbins et al., 2016).

Therefore, considering future research on financial indicators several avenues and recommendations have emerged. At an overall level, the complexity and ambiguity which surround financial indicators call for domestic and international standard setters to continue pursuing a consensus on the adoption of standard accounting definitions in order to overcome the "dominant approach of pragmatic empiricism" (Hruza, 2015). Scholars and standard setters should continue building on the convergence on liquidity and solvency measures and on studies with an international reach to develop common indicators. Future research should overcome the present lack of comparative analysis, as it is important to arrive at solutions that are useful in different contexts. The issue is not necessarily whether publications and their findings focus on a single country, but whether similarities across countries make it possible to draw conclusions that can be useful for jurisdictions across borders.

Future research could also investigate further the relationship between financial indicators and the adoption of accrual accounting and IPSAS. This contribution was not able to drill down on this issue because most publications failed to mention which accounting system and standards were in use with the necessary level of detail. Some scholars, also recently, have advocated the adoption of accrual accounting and IPSAS for the public sector (Cohen et al., 2021). Hence, future research could look at accounting systems and national contexts to take into consideration specific models and guidelines to inform the development of financial indicators to assess LG's financial condition.

Moreover, future research should also verify whether financial indicators keep on being popular or whether scholars and practitioners' interest has recently shifted, as signaled by the drop in publications in the last year and a half. Future research might verify whether other tools are becoming more popular to analyze LG's financial condition.

Four additional research avenues have been mentioned in the selected records themselves. First of all, financial measurement in the public sector has tended to be developed to provide legitimacy within an "institutional environment" rather than to inform organizational change and service improvement (Cohen, 2008). In other words, while financial measures tend to be part of top-down systems primarily oriented to accountability and control (Stevens and McGowan, 1983), future research could analyze their impact on improving LG's financial condition to assess whether such systems could serve as a vehicle for performance enhancement and to resist exogenous shocks. This would imply developing simple and easyto-use indicators in a bottom-up approach to serve LG's specific needs (Kao et al., 2010; Sebestova et al., 2018a).

Second, future research could look at the role financial indicators can play in facilitating auditing as well as assessing the impact of financial shocks. Future research could look more closely at whether and how a set of financial ratios calculated based on information from financial statement could allow auditors to get an indication of LG's financial risk (Cohen et al., 2017) and, hence, to support politicians and managers in promptly detecting financial distress and vulnerability (Padovani et al., 2021). Similarly, financial ratios could help appreciate in how far LGs have managed to address audit findings (Hruza, 2015) and in how far crisis countermeasures have supported LG's resilience (Hegedús and Lentner, 2020).

Third, a greater challenge for future research is to explore models that can evaluate the overall sustainability and not merely the financial sustainability of local authorities (Arunachalam et al., 2017). This would mean developing common indicators for economic, 
environmental and social sustainability in such a way as to avoid the proliferation of standards and measures, which has occurred so far, while allowing for some contextual specificity.

Lastly, as an even more daunting task not only for research but for policy, LG's financial standards and statements could be redesigned to better represent the specific working of public finances (Cohen et al., 2012; Pilcher, 2005). Basic issues such as the valuation of individual public items are dealt with differently across local jurisdictions and IPSAS themselves have developed different options. This greatly limits the meaning of comparing financial indicators across LGs that do not adopt the same standards within and across countries. Moreover, risk assessment with respect to both internal and external factors requires a more detailed analysis than debt analysis which treats debt simply as something bad and undesirable (Kluza, 2017a). Future research could look further into LG's credit rating and consider, for example, that debt may be spent on investments which create cash inflows, efficiencies or public value. To this end some scholars suggest that it would be helpful, for example, to design a model to assess the "public productivity" of debt usage (Kluza, 2017b).

\section{Conclusions}

This review has revealed that recent pressures seem to have stimulated the academic debate on financial indicators, but not the development of common ones. The literature on financial indicators has grown, yet no clear picture has emerged on which indicators should be used for which purpose and in which circumstances. Scholars still mostly refer to financial indicators first developed in the 1980s. Many identify liquidity and solvency as the dimensions that influence LG's financial condition, which may offer a starting point for arriving at commonly accepted indicators.

Some inherent issues in using financial indicators have revealed its complexity. A plethora of financial indicators has been developed so far to assess LG's financial condition because of a great ambiguity in terminology and of different methodological approaches, contexts, purposes and users. Financial indicators allow fulfilling transparency and accountability requirements, support performance monitoring and benchmarking, facilitate assessing the financial health of a LG and help it weather an exogenous financial shock. However, with their proliferation and shortcomings they are rarely acted upon or used for decision-making, but mainly reported for attesting financial distress and for compliance purposes (Brusca and Montesinos, 2013).

However, such findings need to be considered within the constraints of a literature review that is based on what has been published and retrieved, so that any claim of generalizability beyond the reviewed material needs to be further verified.

Notwithstanding a recent drop in publications on financial indicators, some authors predict that the demand for financial tools will grow because of increasing volumes of financial resources and information, and because of the mounting complexity of financial relations (Hruza, 2015). Moreover, with a more global and turbulent environment, it is also highly desirable to strengthen the predictive ability of such tools (Arunachalam et al., 2016; Hruza, 2015; Ritonga, 2014). Hence, future research should enhance comparative analysis and favor convergence, appreciate the impact of different accounting systems and standards, explore further the role financial indicators can play in facilitating auditing as well as assessing the impact of global crises, promote unambiguous international definitions and standards and a bottom-up approach, which looks beyond pure financial condition and consider the specificities of public finances.

At the same time, scholars and practitioners may expect too much from financial indicators. A system of indicators may not provide specific answers to why a problem is occurring, nor does it provide a single index to account for financial condition. Yet, it flags

LG financial indicators 
JPBAFM 34,6

88

potential problems, it offers clues to their causes and it gives LGs time to take anticipatory action (Groves et al., 1981).

\section{References}

$*$ = included in the literature review

Adhikari, P. and Gårseth-Nesbakk, L. (2016), "Implementing public sector accruals in OECD member states: major issues and challenges", Accounting Forum, Vol. 40 No. 2, pp. 125-142, doi: 10.1016/ j.accfor.2016.02.001.

Ahrens, T. and Ferry, L. (2020), "Financial resilience of English local government in the aftermath of COVID-19", Journal of Public Budgeting, Accounting and Financial Management, Vol. 32 No. 5, pp. 813-823, doi: 10.1108/JPBAFM-07-2020-0098.

Alvesson, M. and Deetz, S. (2000), Doing Critical Management Research, Sage, London.

*Arunachalam, M., Chen, C. and Davey, H. (2016), "Financial sustainability of local authorities in New Zealand: performance analysis and coping strategies", New Zealand Journal of Applied Business Research, Vol. 14 No. 1, pp. 19-36.

*Arunachalam, M., Chen, C. and Davey, H. (2017), "A model for measuring financial sustainability of local authorities: model development and application", Asia-Pacific Management Accounting Journal, Vol. 12 No. 1, pp. 39-76.

*Atan, R., Abdul Raman, S., Sawiran, M.S., Mohamed, N. and Mail, R. (2010), "Financial performance of Malaysian local authorities: a trend analysis", in CSSR 2010-2010 International Conference on Science and Social Research, pp. 271-276, doi: 10.1109/CSSR.2010.5773782.

*Bătrâncea, I., Bechiş, L., Bătrâncea, L. and Stoia, I. (2013), "Ratios method: a way of measuring the local government performance", Annals of the University of Oradea, Economic Science Series, Vol. 22 No. 2, pp. 296-304.

*Bastida, F., Guillamón, M.-D. and Benito, B. (2014), "Explaining interest rates in local government borrowing", International Public Management Journal, Vol. 17 No. 1, pp. 45-73, doi: 10.1080/ 10967494.2014.874257.

*Bisogno, M., Cuadrado-Ballesteros, B., Santis, S. and Citro, F. (2019), "Budgetary solvency of Italian local governments: an assessment”, International Journal of Public Sector Management, Vol. 32 No. 2, pp. 122-141, doi: 10.1108/IJPSM-11-2017-0328.

Bracci, E., Humphrey, C., Moll, J. and Steccolini, I. (2015), "Public sector accounting, accountability and austerity: more than balancing the books", Accounting, Auditing and Accountability Journal, Vol. 28 No. 6, pp. 878-908, doi: 10.1108/AAAJ-06-2015-2090.

Bracci, E., Papi, L., Bigoni, M., Deidda Gagliardo, E. and Bruns, H.J. (2019), "Public value and public sector accounting research: a structured literature review", Journal of Public Budgeting, Accounting and Financial Management, Vol. 31 No. 1, pp. 103-136, doi: 10.1108/JPBAFM-072018-0077.

*Brown, K.W. (1993), "The 10-point test of financial condition: toward an easy-to-use assessment tool for smaller cities", Government Finance Review, Vol. December, pp. 21-26.

Brusca, I. and Montesinos, V. (2013), "From rhetoric to practice: the case of Spanish local government reforms", Financial Accountability and Management, Vol. 29 No. 4, pp. 354-377, doi: 10.1111/ faam.12019.

*Brusca, I., Olmo, J. and Labrador, M. (2018), "Characterizing the risk factors for financial sustainability in Spanish local governments", in Rodríguez-Bolívar, M.P. and López-Subires, M.D. (Eds), Financial Sustainability and Intergenerational Equity in Local Governments, IGI Global, Hershey, PA, pp. 206-223, doi: 10.4018/978-1-5225-3713-7.ch009.

*Cabaleiro Casal, R. and Buch Gómez, E. (2011), "Impact of size and geographic location on the financial condition of Spanish municipalities", Transylvanian Review of Administrative Sciences, Vol. 34, pp. 22-39. 
*Cabaleiro Casal, R. and Buch Gómez, E.J. (2014), "Is the tax collection effort an indicator of the financial condition of Spanish municipalities?", International Public Management Journal, Vol. 17 No. 4, pp. 564-592, doi: 10.1080/10967494.2014.958806.

*Cabaleiro Casal, R., Buch Gómez, E.J. and Vaamonde Liste, A. (2012), "The dimensions of the financial condition in Spanish municipalities: an empirical analysis", Studies in Fuzziness and Soft Computing, Vol. 287, pp. 137-152, doi: 10.1007/978-3-642-30451-4_10.

*Cabaleiro Casal, R., Buch Gómez, E.J. and Vaamonde Liste, A. (2013), "Developing a method to assessing the municipal financial health", American Review of Public Administration, Vol. 43 No. 6, pp. 729-751, doi: 10.1177/0275074012451523.

*Carini, C. and Teodori, C. (2019), "Making financial sustainability measurement more relevant: an analysis of consolidated financial statement", in Caruana, J., Brusca, I., Caperchione, E., Cohen, S. and Manes Rossi, F. (Eds), Financial Sustainability of Public Sector Entities. The Relevance of Accounting Framework, Palgrave Macmillan, Cham, pp. 103-122.

*Carmeli, A. (2002), "A Conceptual and practical framework of measuring performance of local authorities in financial terms: analysing the case of Israel", Local Government Studies, Vol. 28 No. 1, pp. 21-36, doi: 10.1080/714004135.

Caruana, J., Brusca, I., Caperchione, E., Cohen, S. and Manes Rossi, F. (2019), "Exploring the relevant of accounting frameworks in the pursuit of financial sustainability of public sector entities: a holistic approach", in Caruana, J., Brusca, I., Caperchione, E., Cohen, S. and Manes Rossi, F. (Eds), Financial Sustainability of Public Sector Entities. The Relevance of Accounting Framework, Palgrave Macmillan, Cham, pp. 1-18.

*CICA (2009), Statement of Recommended Practice SORP 4, Indicators of Financial Condition, Canadian Institute of Chartered Accountants, Toronto.

*Citro, F., Lucianelli, G. and Santis, S. (2018), "Financial conditions, financial sustainability, and intergenerational equity in local governments: a literature review", in Rodríguez-Bolívar, M.P. and López-Subires, M.D. (Eds), Financial Sustainability and Intergenerational Equity in Local Governments, IGI Global, Hershey, PA, pp. 101-124, doi: 10.4018/978-1-5225-3713-7.ch005.

*Clark, B.Y. (2015), "Evaluating the validity and reliability of the financial condition index for local governments", Public Budgeting and Finance, Vol. 35 No. 2, pp. 66-88, doi: 10.1111/pbaf.12063.

*Cohen, S., Doumpos, M., Neofytou, E. and Zopounidis, C. (2012), "Assessing financial distress where bankruptcy is not an option: an alternative approach for local municipalities", European Journal of Operational Research, Vol. 218 No. 1, pp. 270-279, doi: 10.1016/j.ejor.2011.10.021.

*Cohen, S., Costanzo, A. and Manes Rossi, F. (2017), "Auditors and early signals of financial distress in local governments”, Managerial Auditing Journal, Vol. 32 No. 3, pp. 234-250, doi: 10.1108/ MAJ-05-2016-1371.

Cohen, S., Manes Rossi, F., Caperchione, E. and Brusca, I. (2021), "Debate: if not now, then when? Covid-19 as an accelerator for public sector accrual accounting in Europe", Public Money and Management, Vol. 41 No. 1, pp. 10-12, doi: 10.1080/09540962.2021.1834714.

*Cohen, S. (2008), "Identifying the moderator factors of financial performance in Greek municipalities", Financial Accountability and Management, Vol. 24 No. 3, pp. 265-294, doi: 10.1111/j.1468-0408.2008.00453.x.

*De Matteis, F. and Preite, D. (2018), "Sustainability management and local governments: a proposal to define the role of financial sustainability", in Rodríguez-Bolívar, M.P. and López-Subires, M.D. (Eds), Financial Sustainability and Intergenerational Equity in Local Governments, IGI Global, Hershey, PA, pp. 31-57, doi: 10.4018/978-1-5225-3713-7.ch002.

*Drew, J. and Dollery, B. (2014), "The impact of metropolitan amalgamations in Sydney on municipal financial sustainability", Public Money and Management, Vol. 34 No. 4, pp. 281-288, doi: 10.1080/ 09540962.2014.920201.

Dumay, J., Guthrie, J. and Puntillo, P. (2015), "Intellectual capital and public sector: a structured literature review”, Journal of Intellectual Capital, Vol. 16 No. 2, pp. 267-284, doi: 10.1108/JIC-02-2015-0014.

LG financial indicators 
JPBAFM 34,6

*Dziekański, P. (2013), "Financial synthetic index and the economic security of the region in the context of local government efficiency", Research Papers of Wroctaw University of Economics, Vol. 324, pp. 46-61.

*Dziekański, P. (2016), "Efficiency of the municipality's action in the context of the synthetic assessment of the financial condition on the example of the Kamienna Basin municipalities", Scientific Proceedings of Ostroh Academy National University Series, Economics, Vol. 29 No. 1, pp. 87-94.

*Dziekański, P. (2017), "Diversification synthetic indicator for evaluating the financial capacity of local government. The case of polish voivodeships", Acta Universitatis Agriculturae et Silviculturae Mendelianae Brunensis, Vol. 65 No. 2, pp. 611-619, doi: 10.11118/ actaun201765020611.

*Fafurida, F. and Pratiwi, E.N. (2017), "Financial independence of regencies and cities in Central Java", Economic Journal of Emerging Markets, Vol. 9 No. 2, pp. 199-209, doi: 10.20885/ejem.vol9. iss2.art9.

*García-Sánchez, I.-M., Cuadrado-Ballesteros, B., Frías-Aceituno, J.-V. and Mordan, N. (2012), “A new predictor of local financial distress", International Journal of Public Administration, Vol. 35 No. 11, pp. 739-748, doi: 10.1080/01900692.2012.679173.

Garlatti, A., Fedele, P., Iacuzzi, S. and Garlatti Costa, G. (2020), "Coproduction and cost-efficiency: a structured literature review", Journal of Budgeting, Accounting and Financial Management, Vol. 32 No. 1, pp. 114-135, doi: 10.1108/JPBAFM-12-2018-0142.

*Gerrish, E. and Spreen, T.L. (2017), "Does benchmarking encourage improvement or convergence? Evaluating North Carolina's fiscal benchmarking tool", Journal of Public Administration Research and Theory, Vol. 27 No. 4, pp. 596-614, doi: 10.1093/jopart/mux018.

*Gorina, E., Maher, C. and Joffe, M. (2018), "Local fiscal distress: measurement and prediction”, Public Budgeting and Finance, Vol. 38 No. 1, pp. 72-94, doi: 10.1111/pbaf.12165.

*Greganova, R.H., Orszaghova, D. and Papcunova, V. (2015), "The debt service of the municipalities and its impact on the financial management of the municipalities in Slovakia", in Jedlicka, P. (Ed.), Hradec Economic Days, University Hradec Kralove, Kralove, pp. 216-222.

*Groves, S.M., Godsey, W.M. and Shulman, M.A. (1981), "Financial Indicators for local government", Public Budgeting and Finance, Vol. 1 No. 2, pp. 5-19, doi: 10.1111/1540-5850.00511.

*Grzebyk, M. (2012), "Ratio analysis of the financial situation of urban municipalities in the province of Podkarpackie in the years 2008-2010", in Stefko, R., Frankovsky, M. and Vravec, J. (Eds), Management 2012: Research in Management and Business in the Light of Practical Needs, University of Presov, Presov, pp. 102-106.

Guthrie, J., Humphrey, C., Jones, L.R. and Olson, O. (2005), International Public Financial Management Reform: Progress, Contradictions, and Challenges, Information Age Publishing, Greenwich, CT.

*Hegedüs, S. and Lentner, C. (2020), "Comparative analysis of budgetary indicators of European municipal subsystems in the post-crisis term between 2009-2018", Public Finance Quarterly, Vol. 65, pp. 112-133, doi: 10.35551/PFQ_2020_1_8.

Hendrick, R. (2004), "Assessing and measuring the fiscal heath of local governments: focus on Chicago suburban municipalities", Urban Affairs Review, Vol. 40 No. 1, pp. 78-114, doi: 10.1177/ 1078087404268076 .

*Hepworth, N. (1989), "Control of local government finance", Financial Accountability and Management, Vol. 5 No. 2, pp. 119-130, doi: 10.1111/j.1468-0408.1989.tb00312.x.

Hood, C. (1995), "The 'new public management' in the 1980s: variations on the theme", Accounting, Organizations Society, Vol. 20 Nos 2-3, pp. 93-109, doi: 10.1016/0361-3682(93)E0001-W.

*Hruza, F. (2015), "Public sector organization financial ratios' recent development as a matter of financial innovation", Investment Management and Financial Innovations, Vol. 12 No. 2, pp. 88-95.

*Hughes, J. and Katwal, M. (2011), "Use of key financial indicators by local, national and international governments", Journal of Government Financial Management, Vol. 60 No. 3, pp. 46-50. 
Hyndman, N. and Liguori, M. (2016), "Public sector reforms: changing contours on an NPM landscape", Financial Accountability and Management, Vol. 32 No. 1, pp. 5-32, doi: 10.1111/ faam.12078.

*Kao, Y., Ding, H. and Brima, T. (2010), "Local government debt risk early-warning system and empirical analysis", in Proceedings - 2010 IEEE International Conference on Emergency Management and Management Sciences, ICEMMS, pp. 13-15, doi: 10.1109/ICEMMS.2010. 5563515.

*Kazlauskiene, V. and Aidukiene, L. (2014), "Assessing the financial condition of Lithuanian municipalities in rural regions”, in Mazure, G. (Ed.), Economic Science for Rural Development: Finance and Taxes - New Dimensions in the Development of Society, University of Agriculture, Riga, Latvia, pp. 108-116.

Kioko, S.N., Marlowe, J., Matkin, D.S.T., Moody, M., Smith, D.L. and Zhao, Z.J. (2011), "Why public financial management matters”, Journal of Public Administration Research and Theory, Vol. 21, suppl_1, pp. i113-i124, doi: 10.1093/jopart/muq060.

*Kloha, P., Weissert, C.S. and Kleine, R. (2005), "Someone to watch over me: state monitoring of local fiscal conditions", American Review of Public Administration, Vol. 35 No. 3, pp. 236-255, doi: $10.1177 / 0275074005277435$.

*Kluza, K. (2017a), "Changes in the credit risk profile of polish local governments. An assessment of unsystematic risk", Argumenta Oeconomica, Vol. 39 No. 2, pp. 167-192, doi: 10.15611/aoe.2017. 2.07 .

*Kluza, K. (2017b), "Risk assessment of the local government sector based on the ratio analysis and the DEA method. Evidence from Poland”, Eurasian Economic Review, Vol. 7 No. 3, pp. 329-351, doi: 10.1007/s40822-017-0075-z.

Krippendorff, K. (2013), Content Analysis. An Introduction to its Methodology, SAGE Publications, Thousand Oaks, CA.

Lapsley, I., Mussari, R. and Paulsson, G. (2009), "On the adoption of accrual accounting in the public sector: a self-evident and problematic reform”, European Accounting Review, Vol. 18 No. 4, pp. 719-723, doi: 10.1080/09638180903334960.

*Liuta, O., Pihul, N. and Kubakh, T. (2015), "Financial capacity of local budget as a basis for sustainable functioning of a territory", Economic Annals-XXI, Vols 1-2 No. 1, pp. 78-81.

*Mahbub, A.B.M., Alam, M. and Hoque, A. (2017), "Measuring financial condition of urban local government: a study of municipalities in Bangladesh", Journal of Developing Areas, Vol. 51 No. 2, pp. 71-84.

*Maher, C. and Nollenberger, K. (2009), "Revisiting ken Brown's 10-point test”, Government Finance Review, Vol. 25 No. 5, pp. 61-66.

*Maher, C.S., Oh, J.W. and Liao, W.J. (2020), “Assessing fiscal distress in small county governments", Journal of Public Budgeting, Accounting and Financial Management, Vol. 32 No. 4, pp. 691-711, doi: 10.1108/JPBAFM-02-2020-0016.

*Manes Rossi, F., Zito, M. and Costanzo, A. (2012), "How to prevent distress in local government: a new model applied in Italy", Advanced Research in Scientific Areas, Vol. 7, pp. 627-631.

Manes Rossi, F., Cohen, S., Caperchione, E. and Brusca, I. (2016), "Harmonizing public sector accounting in Europe: thinking out of the box", Public Money and Management, Vol. 36 No. 3, pp. 189-196, doi: 10.1080/09540962.2016.1133976.

Manes Rossi, F., Orelli, R.L. and Padovani, E. (2017), “Accounting for financial sustainability. Different local governments choices in different governance settings", in Rodríguez-Bolívar, M. (Ed.), Financial Sustainability in Public Administration, Palgrave Macmillan, Cham, pp. 109-138.

Manes Rossi, F., Nicolò, G. and Argento, D. (2020), "Non-financial reporting formats in public sector organizations: a structured literature review", Journal of Public Budgeting, Accounting and Financial Management, Vol. 32 No. 4, pp. 639-669, doi: 10.1108/JPBAFM-03-2020-0037.

\section{LG financial} indicators 
JPBAFM 34,6

\section{2}

*Manes Rossi, F. (2011), "Analysis of solvency in Italian local governments: the impact of Basel II", IUP Journal of Financial Risk Management, Vol. 8 No. 3, pp. 17-42.

Massaro, M., Dumay, J. and Guthrie, J. (2016), "On the shoulders of giants: undertaking a structured literature review in accounting", Accounting, Auditing and Accountability Journal, Vol. 29 No. 5, pp. 767-801, doi: 10.1108/AAAJ-01-2015-1939.

*Modlin, S. (2010), "Rationalizing the local government decision-making process. A model for state oversight of local government finances", Public Performance and Management Review, Vol. 33 No. 4, pp. 571-593, doi: 10.2753/PMR1530-9576330403.

*Murray, D. and Dollery, B. (2005), "Local government performance monitoring in new South Wales: re 'at risk' councils really at risk?”, Economic Papers, Vol. 24 No. 4, pp. 332-345.

*Mustafin, A.N., Bednarova, L. and Juskova, M. (2017), "Use of regression analysis in municipal evaluation. Case study use of regression analysis in municipal evaluation", Journal of Fundamental and Applied Sciences, Vol. 9 No. 1SI, pp. 1849-1858, doi: 10.4314/jfas.v9i1s.825.

*Natrini, N.D. and Ritonga, I.T. (2017), "Design and analysis of financial condition local government Java and Bali (2013-2014)", in AbdulTalib, Y.Y. (Ed.), The 17th Annual Conference of the Asian Academic Accounting Association (2016 FOURA Conference), doi: 10.1051/shsconf/ 20173403003.

*Navarro-Galera, A., Rodríguez-Bolívar, M.P., Alcaide-Muñoz, L. and López-Subires, M.D. (2016), "Measuring the financial sustainability and its influential factors in local governments", Applied Economics, Vol. 48 No. 41, pp. 3961-3975, doi: 10.1080/00036846.2016.1148260.

Oulasvirta, L. (2014), "The reluctance of a developed country to choose international public sector accounting standards of the IFAC. A critical case study", Critical Perspectives on Accounting, Vol. 25 No. 3, pp. 272-285, doi: 10.1016/j.cpa.2012.12.001.

*Özkul, F. and Alkan, B.Ş. (2017), "Financial condition analysis in municipalities: a case of Turkey", Belediyelerde Mali Durum Analizi: Türkiye Örneği, Vol. 12 No. 48, pp. 153-174.

*Padovani, E., Young, D.W. and Scorsone, E. (2018), "The role of a municipality's financial health in a firm's siting decision”, Business Horizons, Vol. 61 No. 2, pp. 181-190, doi: 10.1016/j.bushor.2017. 09.016.

Padovani, E., Iacuzzi, S., Jorge, S. and Pimentel, L. (2021), "Municipal financial vulnerability in pandemic crises: a framework for analysis", Journal of Public Budgeting, Accounting and Financial Management, Vol. 33 No. 4, pp. 387-408, doi: 10.1108/JPBAFM-07-2020-0129.

*Papcunova, V., Greganova, R.H. and Orszaghova, D. (2015), "Evaluating of the financial management of the municipalities via parameters of data matrix in the Slovak Republic conditions", in Proceedings from IX International Conference on Applied Business Research (ICABR), Mendel University Brno, Brno, Czech Republic, pp. 803-814.

*Petersen, J.E. (1977), "Simplification and standardization of state and local government fiscal indicators", National Tax Journal, Vol. 30 No. 3, pp. 299-311.

*Pilcher, R. (2005), "Local government financial key performance indicators - not so relevant, reliable and accountable", International Journal of Productivity and Performance Management, Vol. 54 Nos 5-6, pp. 451-467, doi: 10.1108/17410400510604584.

Pina, V., Torres, L. and Yetano, A. (2009), "Accrual accounting in EU local governments: one method, several approaches”, European Accounting Review, Vol. 18 No. 4, pp. 765-807, doi: 10.1080/ 09638180903118694.

Pollitt, C. and Bouckaert, G. (2017), Public Management Reform: A Comparative Analysis - into the Age of Austerity, Oxford University Press, Oxford.

*Pridgen, A.K. and Wilder, W.M. (2013), "Relevance of GASB No. 34 to financial reporting by municipal governments", Accounting Horizons, Vol. 27 No. 2, pp. 175-204, doi: 10.2308/ acch-50377.

*Ritonga, I.T., Clark, C. and Wickremasinghe, G. (2012), "Assessing financial condition of local government in Indonesia: an exploration”, Public and Municipal Finance, Vol. 1 No. 2, pp. 37-50. 
*Ritonga, I.T. (2014), "Developing a measure of local government's financial condition”, Journal of Indonesian Economy and Business, Vol. 29 No. 2, pp. 142-164.

*Rivenbark, W.C. and Roenigk, D.J. (2010), “Conceptualizing financial condition in local government", Journal of Public Budgeting, Accounting and Financial Management, Vol. 22 No. 2, pp. 149-177, doi: 10.1108/JPBAFM-22-02-2010-B001.

*Rivenbark, W.C. and Roenigk, D.J. (2011), "Implementation of financial condition analysis in local government”, Public Administration Quarterly, Vol. 35 No. 2, pp. 241-267.

*Robbins, G., Turley, G. and McNena, S. (2016), "Benchmarking the financial performance of local councils in Ireland", Administration, Vol. 64 No. 1, pp. 1-27, doi: 10.1515/admin-2016-0009.

Santis, S., Grossi, G. and Bisogno, M. (2018), "Public sector consolidated financial statements: a structured literature review", Journal of Public Budgeting, Accounting and Financial Management, Vol. 30 No. 2, pp. 230-251, doi: 10.1108/JPBAFM-02-2018-0017.

*Sebestova, J., Majerova, I. and Szarowska, I. (2018a), "Indicators for assessing the financial condition and municipality management", Administratie Si Management Public, Vol. 31, pp. 97-110, doi: 10.24818/amp/2018.31-07.

*Sebestova, J., Majerova, I. and Szarowska, I. (2018b), "Transparency in the municipality spending: financial health index", Tofan, M., Bilan, I. and Bercu, A.M. (Ed. s), EUFIRE 2018: European Financial Regulation, European Commission, Brussels, pp. 177-189.

Steccolini, I., Saliterer, I. and Guthrie, J. (2020), "The role(s) of accounting and performance measurement systems in contemporary public administration”, Public Administration, Vol. 98, pp. 3-13, doi: 10.1111/padm.12642.

*Stevens, J.M. and McGowan, R.P. (1983), "Financial indicators and trends for local governments: a state-based policy perspective", Review of Policy Research, Vol. 2 No. 3, pp. 407-416, doi: 10.1111/ j.1541-1338.1983.tb00726.x.

*Susanto, D. and Djuminah, D. (2015), "The Usefulness of local government financial statements for regional development planning process. An empirical study against the head of the district development planning agencies in Java and Madura”, Pirzada, K., Wickramasinghe, D., Moens, G.A. and Hamid, A.F.A. (Eds), 2nd Global Conference on Business and Social Sciences (GCBSS2015) on "Multidisciplinary Perspectives on Management and Society, pp. 75-80, doi: 10.1016/j. sbspro.2015.11.012.

*Trussel, J.M. and Patrick, P.A. (2013), "The symptoms and consequences of fiscal distress in municipalities: an investigation of reductions in public services", Accounting and the Public Interest, Vol. 13 No. 1, pp. 151-171, doi: 10.2308/apin-10373.

*Trussel, J.M. and Patrick, P.A. (2018), "Assessing and ranking the financial risk of municipal governments: the case of Pennsylvania”, Journal of Applied Accounting Research, Vol. 19 No. 1, pp. 81-101, doi: 10.1108/JAAR-05-2016-0051.

*Turley, G., Robbins, G. and McNena, S. (2015), "A framework to measure the financial performance of local governments”, Local Government Studies, Vol. 41 No. 3, pp. 401-420, doi: 10.1080/03003930. 2014.991865.

*Turley, G., Di Medio, R. and McNena, S. (2020), “A reassessment of local government's financial position and performance: the case of Ireland”, Administration, Vol. 68 No. 2, pp. 1-35, doi: 10.2478/admin-2020-0009.

Vivian, B. and Maroun, W. (2018), "Progressive public administration and new public management in public sector accountancy: an international review", Meditari Accountancy Research, Vol. 26 No. 1, pp. 44-69, doi: 10.1108/MEDAR-03-2017-0131.

Walker, R.M. and Andrews, R. (2015), "Local government management and performance: a review of evidence", Journal of Public Administration Research and Theory, Vol. 25 No. 1, pp. 101-133, doi: 10.1093/jopart/mut038.
LG financial indicators 
JPBAFM 34,6

\section{4}

*Winarna, J., Widagdo, A.K. and Setiawan, D. (2017), "Financial distress of local government: a study on local government characteristics, infrastructure, and financial condition”, Global Business and Finance Review, Vol. 22 No. 2, pp. 34-47, doi: 10.17549/gbfr.2017.22.2.34.

*Wojtasiak-Terech, A. and Makowska, A. (2017), "Assessing financial condition of municipalities using taxonomic methods", Nesleha, J., Plihal, T. and Urbanovsky, K. (Eds), European Financial Systems 2017: Proceedings of the 14th International Scientific Conference, Masaryk University Brno, pp. 466-473.

*Yi, L. (2009), "An empirical analysis of a monitoring system of local fiscal risk", in Proceedings International Conference on Management and Service Science, MASS, doi: 10.1109/ICMSS.2009. 5301746.

Yin, R.K. (2014), Case Study Research: Design and Methods, Sage Publications, Thousand Oaks, CA.

*Zafra-Gómez, J.L., López-Hernández, M.A. and Hernández-Bastida, A. (2009), "Evaluating financial performance in local government: maximizing the benchmarking value", International Review of Administrative Sciences, Vol. 75 No. 1, pp. 151-167, doi: 10.1177/0020852308099510.

*Zarska, E. and Rafaj, O. (2016), "Financial condition of a city for generating its own development", in Stejskal, J. and Krupka, J. (Eds), Proceedings of the 11th International Scientific Conference Public Administration 2016, University of Pardubice, Pardubice, pp. 310-318.

\section{Further reading}

*Andrews, R. (2015), "Vertical consolidation and financial sustainability: evidence from English local government", Environment and Planning C: Government and Policy, Vol. 33, pp. 1518-1545, doi: 10.1177/0263774X15614179.

*Providence, C. (2019), "Nine indicators to assess the financial issues of local government administration in Haiti", Scholedge International Journal of Management and Development, Vol. 6 No. 2, pp. 7-24, doi: 10.19085/journal.sijmd060201.

\section{Corresponding author}

Silvia Iacuzzi can be contacted at: silvia.iacuzzi@uniud.it

For instructions on how to order reprints of this article, please visit our website:

www.emeraldgrouppublishing.com/licensing/reprints.htm

Or contact us for further details: permissions@emeraldinsight.com 